\title{
Stimulation of Rat Hepatic Low Density Lipoprotein Receptors by Glucagon Evidence of A Novel Regulatory Mechanism In Vivo
}

\author{
Mats Rudling and Bo Angelin \\ Metabolism Unit, Department of Medicine, and Molecular Nutrition Unit, Center for Nutrition and Toxicology, \\ Karolinska Institutet at Huddinge University Hospital, S-141 86 Huddinge, Sweden
}

\section{Abstract}

We studied the influence of glucagon on hepatic LDL receptors and plasma lipoproteins in rats. A dose-dependent (maximum, threefold) increase in LDL-receptor binding was evident already at a dose of $2 \times 4 \mu \mathrm{g}$, and detectable $3 \mathrm{~h}$ after injection; concomitantly, cholesterol and apolipoprotein (apo) $B$ and apoE within LDL and large HDL decreased in plasma. LDL receptor mRNA levels were however unaltered or reduced. Hepatic microsomal cholesterol was increased and the enzymatic activities of 3-hydroxy-3-methylglutaryl coenzyme A reductase and cholesterol $7 \alpha$-hydroxylase in hepatic microsomes were reduced.

Insulin alone increased receptor binding and receptor mRNA levels twofold, but plasma cholesterol was unchanged and plasma apoE and apoB increased. Administration of insulin to glucagon-treated animals reduced the LDL-receptor binding to control levels and apoB appeared in LDL particles. Estrogen treatment increased LDL-receptor binding and mRNA levels five- and eightfold, respectively. Combined treatment with glucagon and estrogen reduced the stimulation of LDL-receptor mRNA levels by $80 \%$ although LDL-receptor binding was unchanged. Immunoblot analysis showed that glucagon increased the number of hepatic LDL receptors.

We conclude that glucagon induces the number of hepatic LDL receptors by a mechanism not related to increased $m$ RNA levels, suggesting the presence of a posttranscriptional regulatory mechanism present in the liver in vivo. (J. Clin. Invest. 1993. 91:2796-2805.) Key words: cholesterol • cholesterol $7 \alpha$-hydroxylase $\cdot 3$-hydroxy-3-methylglutaryl coenzyme A reductase $\bullet$ insulin $\bullet$ plasma lipoproteins

\section{Introduction}

Stimulation of the activity of receptors for LDL in the liver is a major mechanism for reducing the plasma concentration of these atherogenic lipoproteins $(1,2)$. Thus, by pharmacological interaction with bile acid enterohepatic circulation, or by inhibition of cholesterol biosynthesis in the liver, the expression of hepatic LDL receptors can be increased in animals and man (3-5). Furthermore, treatment with estrogen or growth hormone can induce hepatic LDL receptor expression consider-

Address correspondence to Dr. Mats Rudling, Metabolism Unit, Department of Medicine, Huddinge University Hospital, S-141 86 Huddinge, Sweden.

Received for publication 8 September 1992 and in revised form 20 January 1993.

J. Clin. Invest.

(C) The American Society for Clinical Investigation, Inc.

$0021-9738 / 93 / 06 / 2796 / 10 \quad \$ 2.00$

Volume 91, June 1993, 2796-2805 ably (6-8). When added to cultured cells of hepatic origin, hormones such as insulin and thyroxin also stimulate LDL receptor binding activity in vitro $(9,10)$. In all these situations, the increased LDL receptor expression is paralleled by enhanced levels of LDL receptor mRNA (8-13). However, experiments on cultured cells have suggested that the LDL receptor may also be regulated posttranscriptionally (14-18). The crucial question of whether such mechanisms demonstrated in vitro may also occur in the liver in vivo has not yet been elucidated.

Glucagon has an important role in carbohydrate metabolism, together with insulin being a major regulator of plasma glucose concentration (19). Glucagon also exhibits effects on cholesterol metabolism, but its physiological role in this context remains unclear. Conditions with increased glucagon levels are associated with reduced plasma cholesterol levels (2022 ), and the administration of glucagon to laboratory animals and man decreases plasma cholesterol levels (23-25). In contrast, manipulations lowering glucagon levels, such as subtotal pancreatectomy (26) or treatment with cobaltous chloride (27), rapidly result in a marked hypercholesterolemia that can be counteracted by the administration of glucagon $(24,26)$. Recently, it has been shown that the LDL-receptor activity of liver cells in primary culture increased upon exposure to glucagon (28). To date, no information is available as regards effects of glucagon on hepatic LDL receptors in vivo.

In the current study, we addressed the question whether glucagon administration could alter hepatic LDL-receptor activity in vivo. It was shown that when glucagon was given subcutaneously to rats, the hepatic LDL-receptor binding increased rapidly, with a concomitant reduction of plasma cholesterol within LDL and large HDL. However, glucagon did not increase the mRNA levels for the LDL receptor. It is suggested that glucagon has an important role in the regulation of hepatic LDL receptors, presumably exerted via a novel mechanism, thereby influencing the plasma levels of LDL cholesterol.

\section{Methods}

Materials. Glucagon and insulin (Novotard ${ }^{\oplus}, 100 \mathrm{IU} / \mathrm{ml}$ ) were from A/S Novo (Copenhagen, Denmark). Goat anti-mouse IgG (catalog No. M-8642, lot No. 70H8945) was from Sigma Chemical Company (St. Louis, MO). All other reagents and chemicals were from sources previously described $(8,13,31,32)$.

Animals, experimental procedure. 82 male Sprague-Dawley rats (250-350 g, 7-12 wks) were used. Animals were kept under standardized conditions with free access to water and chow. The light cycle hours were between 6 a.m. and 6 p.m.

Rats were injected under light ether anesthesia, at 9 a.m. and 4 p.m., with $400 \mu \mathrm{g}(115 \mathrm{nmol})$ s.c. of glucagon, if not stated otherwise. A similar protocol was used when insulin $(10 \mathrm{IU} \times 2 / \mathrm{d})$ was administered. Rats receiving ethinylestradiol $(5 \mathrm{mg} / \mathrm{kg}$ per $\mathrm{d}$ s.c. $)$ were injected at 9 a.m. (8). Control rats received vehicle. Animals were killed at 11 
a.m., $2 \mathrm{~h}$ after the last injection, as described previously (8). When the enzymatic activities of 3-hydroxy-3-methylglutaryl coenzyme A reductase (HMG CoA reductase) ${ }^{1}$ and cholesterol $7 \alpha$-hydroxylase were assayed, $1 \mathrm{~g}$ of fresh liver was taken for preparation of microsomes.

Size-fractionation of lipoproteins by fast protein liquid chromatography (FPLC). Equal volumes of plasma from each animal were pooled $(4 \mathrm{ml})$, and the density was raised to $1.21 \mathrm{~g} / \mathrm{ml}$ with $\mathrm{KBr}$. After ultracentrifugation at $100 \times 10^{3} \mathrm{~g}$ for $48 \mathrm{~h}$, the removed supernatant was adjusted with $0.15 \mathrm{M} \mathrm{NaCl}, 0.01 \%$ EDTA, $0.02 \%$ sodium azide, $\mathrm{pH}$ 7.3 , to $2.66 \mathrm{ml}$, and $2 \mathrm{ml}$ of this solution, corresponding to $3 \mathrm{ml}$ of plasma, was injected on a $54 \times 1.8 \mathrm{~cm}$ Superose $6 \mathrm{~B}$ column after filtration through a $0.45-\mu \mathrm{m}$ HA filter (Millipore Corp., Bedford, MA); 2-ml fractions were collected $(13,29)$.

SDS-PAGE separation of size-fractionated lipoproteins. FPLC fractions $(1.32 \mathrm{ml})$ were precipitated with trichloroacetic acid, washed with acetone and solubilized in $200 \mu \mathrm{l}$ buffer as described elsewhere (13). Samples $(80 \mu \mathrm{l})$ were separated $(4.5 \mathrm{~h}, 40 \mathrm{~mA} / \mathrm{gel})$, on 4-20\% gradient gels after boiling for $5 \mathrm{~min}$ in the presence of $5 \% \beta$-mercapthoethanol. Gels were stained with Coomassie blue and calibrated with human LDL, high (Bio-Rad Laboratories, Richmond, CA) and low (Pharmacia Fine Chemicals, Piscataway, NJ) molecular mass standards containing the following size markers: human $\mathrm{LDL}=\operatorname{apoB}(\approx 512 \mathrm{kD})$, myosin ( $200 \mathrm{kD}), \beta$-galactosidase ( $116 \mathrm{kD})$, phosphorylase $b(97 \mathrm{kD})$, albumin (66 kD), ovalbumin (45 kD), carbonic anhydrase (30 kD), soybean trypsin inhibitor ( $20 \mathrm{kD}$ ), and $\alpha$-lactalbumin ( $14 \mathrm{kD})$. Size markers were reduced and boiled as described for FPLC fractions.

Preparation of hepatic membranes and ligand blot assay of $L D L$-receptors. This was performed using ${ }^{125} \mathrm{I}$-labeled rabbit $\beta$-migrating VLDL ( $\beta$-VLDL) exactly as described previously ( 8$)$. Gels (6\% SDSPA) were loaded with the indicated amount of membrane protein. Size markers were treated as described above. Filters were exposed on Kodak XAR-film for the indicated times as described (8). LDL-receptor binding activity in blots was quantitated by $\gamma$-counting of cut-out 120 $\mathrm{kD}$ bands localized using superimposed transparent film. Background $\mathrm{cpm}$ (given in each figure legend) were obtained by counting of four irrelevant filter pieces of the same area and have been subtracted from the data. In one experiment (Fig. 8), LDL receptors were quantitated by immunoblot analysis using a mouse monoclonal antipeptide antibody (IgG-4A4; reference 30 ) kindly provided by Drs. M. S. Brown and Y. K. Ho, Department of Molecular Genetics, University of Texas Health Science Center at Dallas, TX. This antibody is directed against the intracellular carboxy-terminal 12 amino acids of the LDL receptor. The $120-\mathrm{kD}$ bands were analyzed in a PhosphorImager ${ }^{\circledR}$ ( model 200B; Molecular Dynamics, Sunnyvale, CA). Data are given as arbitrary units (AU) after subtraction of background activity measured from identical filter areas of an empty parallel lane. When more than one lane was run per animal group, the average filter cpm or AU were calculated and normalized to membrane protein.

Cholesterol assays. Hepatic cholesterol was extracted from $0.2 \mathrm{~g}$ liver samples as described elsewhere (13). Cholesterol in plasma, FPLC fractions, and hepatic extracts was assayed with the Nycotest ${ }^{\otimes}$ kit ( Nycomed, Oslo, Norway), using a 5.2-mM cholesterol standard (Merck System, Darmstadt, Germany; catalog No. 14164).

mRNA quantitation. Hepatic total RNA was isolated by ultracentrifugation on $\mathrm{CsCl}$ of $0.5 \mathrm{~g}$ of liver homogenized in $4 \mathrm{ml}$ guanidinium thiocyanate as described (13). mRNA levels for the LDL receptor, HMG CoA reductase, and cholesterol $7 \alpha$-hydroxylase were quantitated by solution hybridization using mouse cRNA probes (13). The mRNA abundancies are expressed as copies of mRNA molecules/cell, assuming $15 \mathrm{pg}$ of RNA/cell; this is not an absolute quantification.

Hepatic microsomal activities of HMG CoA reductase and cholesterol $7 \alpha$-hydroxylase. Microsomes were prepared by differential ultracentrifugation of liver homogenates in the absence of fluoride as de-

1. Abbreviations used in this paper: FPLC, fast protein liquid chromatography; HMG-CoA reductase, 3-hydroxy-3-methylglutaryl coenzyme A reductase. scribed previously $(31,32)$. Microsomal HMG CoA reductase was assayed by determining the conversion of $\left[{ }^{14} \mathrm{C}\right] \mathrm{HMG} \mathrm{CoA}$ to mevalonate and expressed as pmol formed per mg protein per $\min (31)$. The activity of cholesterol $7 \alpha$-hydroxylase was determined as the formation of $7 \alpha$-hydroxycholesterol ( $\mathrm{pmol} / \mathrm{mg}$ protein per $\mathrm{min}$ ) by isotope dilution-mass spectrometry as described (32).

Statistical methods. Data are presented as means and SEM. Significances of differences between data of glucagon-treated rats and controls presented in Table I were evaluated by two-tailed Student's $t$ test (33). All data in Figs. 1 and 2, $A-C$ were evaluated for the presence of significant $(P<0.05)$ differences between groups by ANOVA followed by comparisons among class means as described in (33). Test for linearity of regression was made as described (33), using a level of significance of 5\%. In the two two-factorial experiments presented in Table II (insulin experiment) and Fig. 7 (estrogen experiment), each single treatment and the interaction when the two treatments were combined were evaluated statistically as described in (33) for the $2^{2}$ factorial experiment. In order to achieve stability of variances, data were log transformed if ranges of group averages exceeded 3 (33). Correlations were tested by calculating the correlation coefficient, $r(33)$.

\section{Results}

To determine the influence of glucagon on hepatic LDL-receptor binding and plasma cholesterol, we treated groups of three

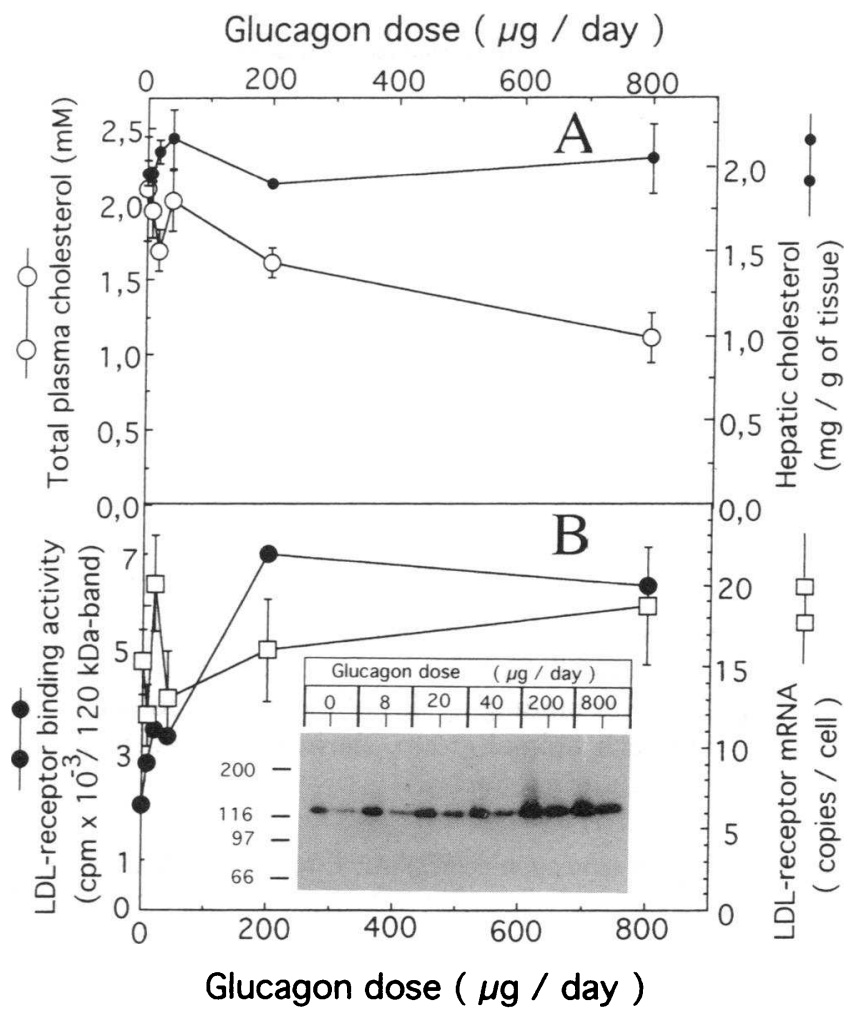

Figure 1. Effect of glucagon dose on plasma $(0)$ and hepatic $(\bullet)$ cholesterol $(A)$, and hepatic LDL-receptor binding $(\bullet)$ and mRNA ( $\square)$ $(B)$. Rats (3/group) were injected twice daily with the indicated doses of glucagon for $4 \mathrm{~d} .2 \mathrm{~h}$ after the last injection, rats were killed and hepatic membranes from each group were prepared from pools of liver samples. (Inset $B$ ) Ligand blot of hepatic membranes. For each group, 200 and $100 \mu \mathrm{g}$ of membrane protein were loaded on the gel, respectively. The filter was exposed on film for $2 \mathrm{~h}$. The average cutout cpm values from the blot are presented in $B(\bullet)$; subtracted filter background was $850 \mathrm{cpm}$. Plasma and hepatic total cholesterol and LDL-receptor mRNA were determined in each individual. Bars $=$ SEM. 

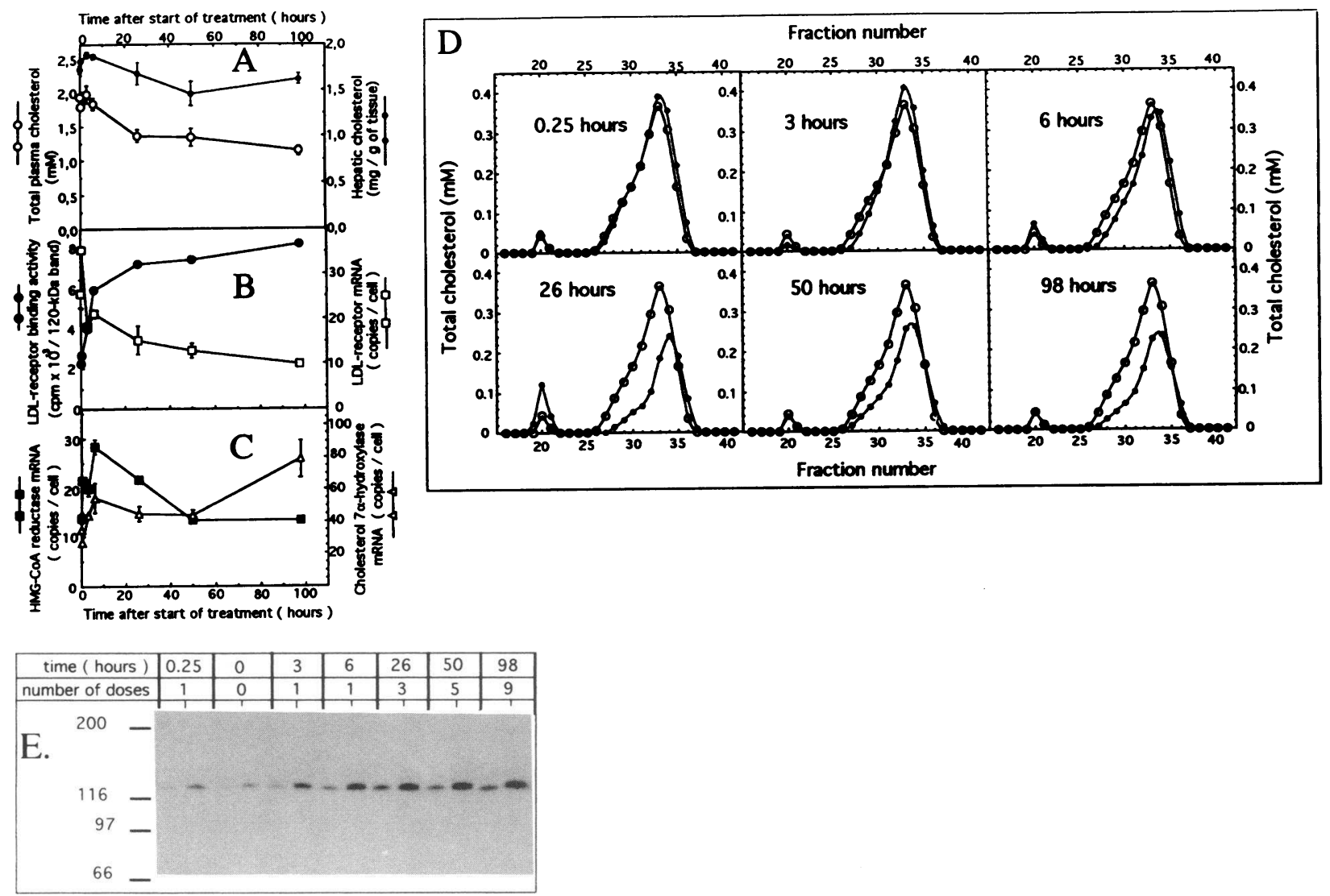

Figure 2. Time course for effects of glucagon. Rats (3/group; except $0.25 \mathrm{~h}$ group that comprised two animals) received injections of glucagon $(400 \mu \mathrm{g} \times 2 \mathrm{~d}$ s.c.) for the indicated times. On day 5 , rats were killed $2 \mathrm{~h}$ after the last dose. In addition, three groups of rats were killed $15 \mathrm{~min}$, $3 \mathrm{~h}$, and $6 \mathrm{~h}$, respectively, after a single $400-\mu \mathrm{g}$ dose of glucagon. Total plasma $(0)$ and hepatic $(\bullet)$ cholesterol $(A)$. In $B$, LDL-receptor binding $(\bullet)$, and LDL-receptor mRNA levels $(\square)$ are shown. HMG CoA reductase $(\bullet)$ and cholesterol $7 \alpha$-hydroxylase $(\Delta)$ mRNA levels are presented in $C$. In A-C, bars = SEM. The changes of plasma lipoproteins with time are shown in $D$. Pooled plasma lipoproteins from each group were separated by FPLC after concentration by ultracentrifugation. The fractions were assayed for total cholesterol; (O) represents the FPLC-pattern of the saline-treated control group, $(\bullet)$ is the pattern of the indicated group. $E$ shows the LDL-receptor binding assayed by ligand blot. Hepatic membranes were prepared from pooled liver tissue; for each group 2 lanes with 100 and $200 \mu \mathrm{g}$ of protein were run. The filter was exposed on film for $2 \mathrm{~h}$. The cpm values of the blot (subtracted filter background was $1,150 \mathrm{cpm}$ ) are shown in $B$.

rats with increasing amounts of glucagon subcutaneously twice daily for $4 \mathrm{~d}$ before killing (Fig. 1). Determination of the hepatic LDL-receptor binding by ligand blot, using pooled liver samples from each animal group, showed a dose-dependent increase in binding evident already at the lowest dose given, 2 $\times 4 \mu \mathrm{g} / \mathrm{d}$ ( inset, Fig. $1 B$ ). The quantitated LDL-receptor binding of this blot is shown in Fig. $1 \mathrm{~B}$. A significant linear dose dependent decrease was obtained for total plasma cholesterol,

Table I. Effects of Glucagon on Hepatic Cholesterol Metabolism

\begin{tabular}{lccc}
\hline & Controls & Glucagon-treated & $P$-value* \\
\hline Total plasma cholesterol $(\mathrm{mM})$ & $2.4 \pm 0.09$ & $1.5 \pm 0.10$ & $<0.001$ \\
Total hepatic cholesterol $(\mathrm{mg} / \mathrm{g})$ & $1.7 \pm 0.05$ & $1.6 \pm 0.04$ & $<0.05$ \\
Total hepatic microsomal cholesterol (mg/g) & $1.7 \pm 0.09$ & $2.1 \pm 0.13$ & $<0.05$ \\
LDL-receptor binding (cpm/100 $\mu$ g protein) & $2,590 \pm 260$ & $5,240 \pm 560$ & $<0.001$ \\
HMG CoA reductase activity (pmol/mg per min) & $232 \pm 31$ & $8.7 \pm 0.37$ & $<0.001$ \\
Cholesterol $7 \alpha$-hydroxylase (pmol/mg per min) & $12 \pm 1.2$ & $31 \pm 4.1$ & NS \\
LDL-receptor mRNA (copies/cell) & $32 \pm 4.9$ & $22 \pm 3.4$ & NS \\
HMG CoA reductase mRNA (copies/cell) & $19 \pm 1.3$ & $43 \pm 3.0$ & NS \\
Cholesterol $7 \alpha$-hydroxylase mRNA (copies/cell) & $37 \pm 4.4$ & & \\
\hline
\end{tabular}

Six rats were treated for $4 \mathrm{~d}$ with two $400-\mu \mathrm{g}$ injections s.c. of glucagon/d prior to killing. Control animals $(n=6)$ received saline. Values are means \pm SEM. ${ }^{*}$ Student's $t$ test. 


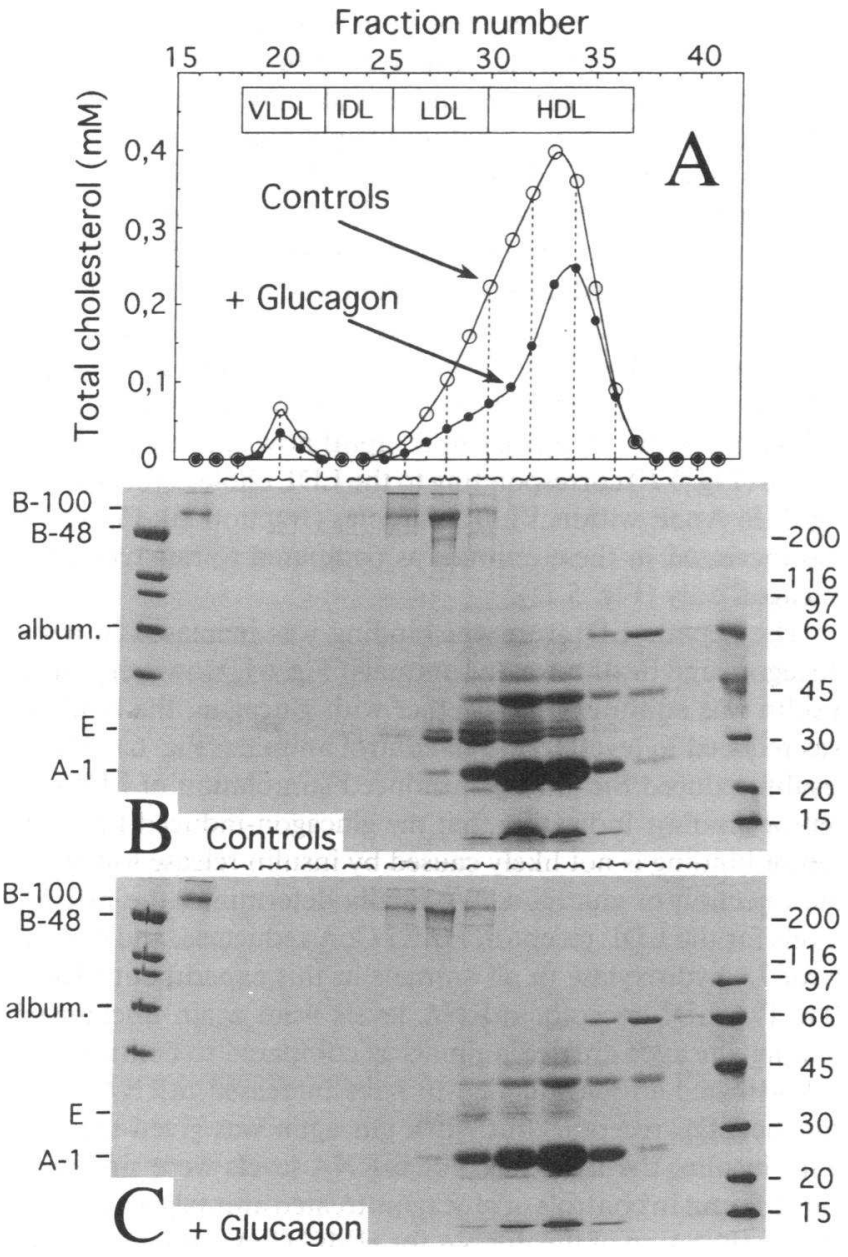

Figure 3. Characterization of plasma lipoprotein changes induced by glucagon treatment. Concentrated lipoproteins from rats described in Table I were separated by FPLC and assayed for cholesterol. $(A)$ $(O)$ controls, $(\bullet)$ glucagon-treated rats. The sites of elution of major lipoproteins are indicated: VLDL, IDL, LDL, and HDL. $(B)$ (controls) and $(C)$ (glucagon-treated) Coomassie-stained SDS-PA gradient gels (4-20\%) after separation of the indicated delipidated FPLC fractions. The stained gels are flanked by the indicated molecular weight size markers.

but not for total hepatic cholesterol (Fig. $1 A$ ). The LDL-receptor mRNA levels in samples from all individuals did, however, not show any significant linear change with increased dose of glucagon (Fig. $1 \mathrm{~B}$ ).

We then determined the time course for the effects of glucagon on cholesterol metabolism, using the highest dose $(400$ $\mu \mathrm{g}$ /injection; Fig. 2 ). The total plasma cholesterol levels were significantly decreased $(P<0.001)$ in all groups of animals treated $\geq 26 \mathrm{~h}$ ( $\geq 3$ injections), whereas no change was found in animals receiving a single dose only (Fig. $2 \mathrm{~A}$ ). Total hepatic cholesterol was only significantly altered $(P<0.05)$ in the group treated for $50 \mathrm{~h}$. To characterize the plasma lipoprotein changes in more detail, pooled plasma from each group was separated by FPLC after ultracentrifugation. It was found that all groups treated $\geq 26 \mathrm{~h}$ ( $\geq 3$ injections) had decreased cholesterol in LDL (fractions 26-29) and large HDL (fractions 3034 ). When animals receiving a single injection were compared

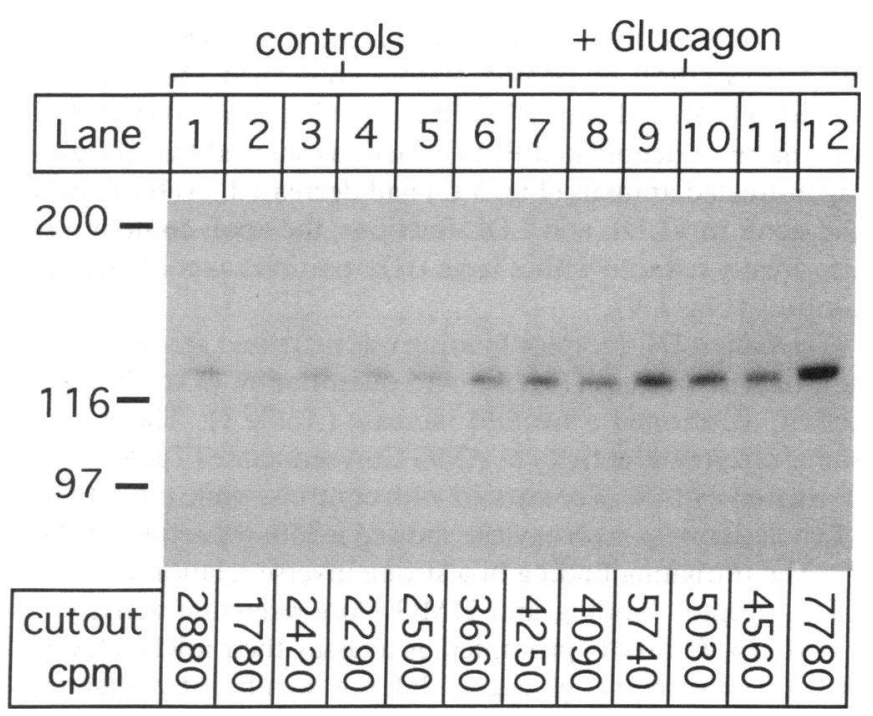

Figure 4. Ligand blot of hepatic membranes from control and glucagon-treated rats from the experiment described in legend to Table I. To each lane, $200 \mu \mathrm{g}$ of membrane protein from each rat was loaded. The filter was exposed on film for $2 \mathrm{~h}$ (subtracted filter background was $1,690 \mathrm{cpm})$.

with controls, no change was found in animals $15 \mathrm{~min}$ after glucagon injection. However, $3 \mathrm{~h}$ after glucagon injection, the cholesterol in the LDL fractions decreased, and $6 \mathrm{~h}$ after injection a further reduction of cholesterol in LDL and large HDL fractions was seen.

The LDL-receptor binding was unchanged among animals killed $15 \mathrm{~min}$ after receiving glucagon (Fig. $2 E$ ). However, an increased binding was seen in the sample from animals $3 \mathrm{~h}$ after glucagon injection, and a further increased binding was observed in animals killed after 6 and $26 \mathrm{~h}$. Quantification of the LDL-receptor binding in this blot (Fig. $2 B$ ) confirmed that near maximal binding occurred after $26 \mathrm{~h}$ (three injections). In this experiment, hepatic LDL-receptor mRNA levels were clearly reduced to $1 / 3$ of initial levels with prolonged glucagon treatment (Fig. $2 B$ ). The reduction appeared to be rapid, and significant already after $3 \mathrm{~h}(P<0.05)$. Determination of the mRNA levels for the rate-determining step in cholesterol biosynthesis, HMG CoA reductase, did not show any significant change with longer times, although a transient significant increase ( $P<0.001)$ occurred $0.15,3$, and $6 \mathrm{~h}$ after single injection as well as in the 26-h group (Fig. $2 C$ ). mRNA for the rate-limiting enzyme in the conversion of cholesterol to bile acids, cholesterol $7 \alpha$-hydroxylase, increased with time in this experiment (Fig. $2 C$ ).

To better monitor the effects of glucagon on cholesterol metabolism, and to allow for a more comprehensive statistical evaluation, 12 rats were injected twice daily with $400 \mu \mathrm{g}$ of glucagon or saline (controls) for $4 \mathrm{~d}$ before killing (Table I, Figs. 3 and 4). All samples were assayed for both mRNA levels and the expression of LDL receptors, and activities of HMG CoA reductase and cholesterol $7 \alpha$-hydroxylase. Furthermore, total cholesterol was determined in plasma, liver, and liver microsomes. In addition, pooled plasma lipoproteins were separated by FPLC for subsequent analysis of cholesterol and apoproteins. In this experiment, glucagon-treated animals again 
showed reduced total plasma cholesterol levels (Table I), and FPLC separation of pooled plasma confirmed that this occurred in LDL and large HDL fractions (Fig. $3 A$ ). SDS-PAGE separation of delipidated FPLC fractions showed that the glucagon-treated animals (Fig. $3 C$ ) had decreased levels of apoB and apoE in VLDL and LDL fractions; the apoE content was also greatly reduced within large HDL particles as compared to controls (Fig. $3 B$ ).

Hepatic LDL-receptor binding was increased among glucagon-treated animals (Fig. 4), and quantitation of the binding activity confirmed a twofold increase (Table I). The microsomal enzymatic activity of HMG CoA reductase (Table I) was decreased by $66 \%$ as compared with controls, while the activity of cholesterol $7 \alpha$-hydroxylase showed a $25 \%$ reduction (Table I). The intriguing finding of a strong inverse relation between LDL-receptor binding and HMG CoA reductase activity ( $r$ $=-0.774, P<0.01)$ prompted us to assay their mRNA levels. In this experiment, glucagon did not significantly alter the mRNA concentration of the LDL-receptor or HMG CoA reductase, nor did it change that of cholesterol $7 \alpha$-hydroxylase (Table I). It could thus be confirmed that glucagon treatment resulted in an increased LDL-receptor binding activity that was not related to an increased LDL-receptor mRNA level.

Since the current results were obtained as a response following the injection of glucagon, it could not be excluded that the LDL-receptor stimulation was caused by a counterregulation following glucagon administration. It is known that insulin, previously shown to stimulate the expression of LDL receptors in vitro (9), is released upon manipulations leading to hyperglycemia, such as glucagon administration (17). To investigate the possibility that insulin release may be responsible for the observed increase in LDL-receptor binding, we compared the effects of glucagon ( $400 \mu \mathrm{g} \times 2 / \mathrm{d})$ to those of insulin at a high dose $(10 \mathrm{IU} \times 2 / \mathrm{d})$; in addition, to allow for the evaluation of the presence of interaction, another group of animals received the above doses of both glucagon and insulin (Table II, Figs. 5 and 6 ). The glucagon-treated animals showed $50 \%$ reductions of plasma cholesterol ( Table II). However, insulin-treated animals had the same plasma cholesterol levels as untreated controls, while animals on combined treatment had slightly lower levels than rats receiving glucagon only.

Analysis of lipoprotein cholesterol after FPLC separation of pooled samples showed that the insulin-treated animals were indistinguishable from the controls (Fig. $5 \mathrm{~A}$ ). The glucagontreated animals again showed the typical reduction of choles- terol among LDL and large HDL (Fig. $5 B$ ). However, the rats given glucagon plus insulin displayed a further reduction of cholesterol in HDL particles and a peak now occurred in the LDL fractions (Fig. $5 \mathrm{~B}$ ). Analysis of apolipoproteins in FPLC fractions (Fig. $5 C-F$ ) showed that apoB and apoE were not decreased in insulin-treated animals; if anything, apoB and particularly apoE levels were increased (compare Fig. $5 E$ to $5 C$ ). The glucagon-treated animals had reduced apoB levels in the LDL fractions, and decreased apoE levels in LDL and large HDL particles (Fig. $5 \mathrm{D}$ ). When glucagon-treated animals in addition received insulin, the low plasma apoE levels increased in fractions 32 to 36 ; furthermore, apoB now appeared in fraction 28 (Fig. $5 F$ ) corresponding to the LDL cholesterol peak in Fig. 5 B. ApoE within VLDL particles (fraction 20; Fig. $5 F$ ) also increased in these animals as compared to rats receiving glucagon only (Fig. $5 \mathrm{D}$ ).

The hepatic LDL-receptor binding was increased in both glucagon- and insulin-treated animals (Fig. 6). However, when insulin was administered together with glucagon, the binding was reduced to levels found in control animals (Fig. 6). Thus, insulin reduced the glucagon-induced stimulation of LDL-receptor binding, indicating that the glucagon-induced LDL-receptor binding is not likely caused by insulin release following the injection of glucagon. We finally determined the mRNA levels for the LDL receptor, HMG CoA reductase, and cholesterol $7 \alpha$-hydroxylase in all animals in this experiment (Table II). The LDL-receptor mRNA levels were again unchanged among glucagon-treated animals as compared to controls. Insulin-treated animals tended to have increased mRNA levels for the LDL receptor, but when glucagon was given together with insulin, the LDL-receptor mRNA levels were similar to those found in controls or glucagon-treated animals. In similarity, quantitation of the mRNA for HMG CoA reductase in this experiment revealed a fourfold increase in the insulin-treated animals, and a significant interaction was obtained when both hormones were administered. Also for the mRNA levels of cholesterol $7 \alpha$-hydroxylase, a highly significant interaction was present when the two hormones were combined (Table II).

To further investigate the effects of glucagon on hepatic LDL-receptor expression in relation to LDL-receptor mRNA levels, we studied its influence in rats treated with high doses of estrogen, an experimental model where very high levels of hepatic LDL receptor and $m R N A$ are induced $(6,8,34)$. Groups of four rats were treated for $4 \mathrm{~d}$ with either vehicle alone (controls), glucagon (400 $\mu \mathrm{g} \times 2)$, estrogen $(5 \mathrm{mg} / \mathrm{kg}$ per $\mathrm{d})$, or

Table II. Effects of Glucagon, Insulin, and their Combination on Hepatic Cholesterol Metabolism

\begin{tabular}{llccc}
\hline & Controls & +Glucagon & +Insulin & +Glucagon + Insulin \\
\hline Total plasma cholesterol $(\mathrm{mM})$ & $2.0 \pm 0.08$ & $1.0 \pm 0.04^{\ddagger}$ & $2.1 \pm 0.09$ & $0.8 \pm 0.08$ \\
Total hepatic cholesterol (mg/g) & $1.6 \pm 0.07$ & $1.4 \pm 0.04$ & $1.6 \pm 0.09$ & $1.4 \pm 0.05$ \\
LDL-receptor mRNA (copies/cell) & $18 \pm 5.5$ & $18 \pm 3.6$ & $28 \pm 2.8$ & $20 \pm 2.1$ \\
HMG CoA reductase mRNA (copies/cell) & $13 \pm 1.9$ & $17 \pm 1.7$ & $43 \pm 5.5^{\ddagger}$ & $28 \pm 3.8^{*}$ \\
Cholesterol 7 $\alpha$-hydroxylase mRNA (copies/cell) & $24 \pm 5.4$ & $85 \pm 8.6^{*}$ & $189 \pm 24^{\ddagger}$ & $146 \pm 24^{\ddagger}$ \\
\hline
\end{tabular}

Four groups of rats (4/group) received subcutaneous injections twice daily for $4 \mathrm{~d}$ of either saline (Control) or $400 \mu \mathrm{g}$ of glucagon (+Glucagon), 10 IU of insulin (+Insulin), or both hormones (+Glucagon + Insulin). The mRNA levels for the LDL-receptor, HMG CoA reductase, and cholesterol $7 \alpha$-hydroxylase were assayed by solution hybridization as described. Values are means \pm SEM. ${ }^{*} P<0.02,{ }^{\ddagger} P<0.005$ when analyzed by factor test for the effects of glucagon, insulin, and presence of interaction (combination). 


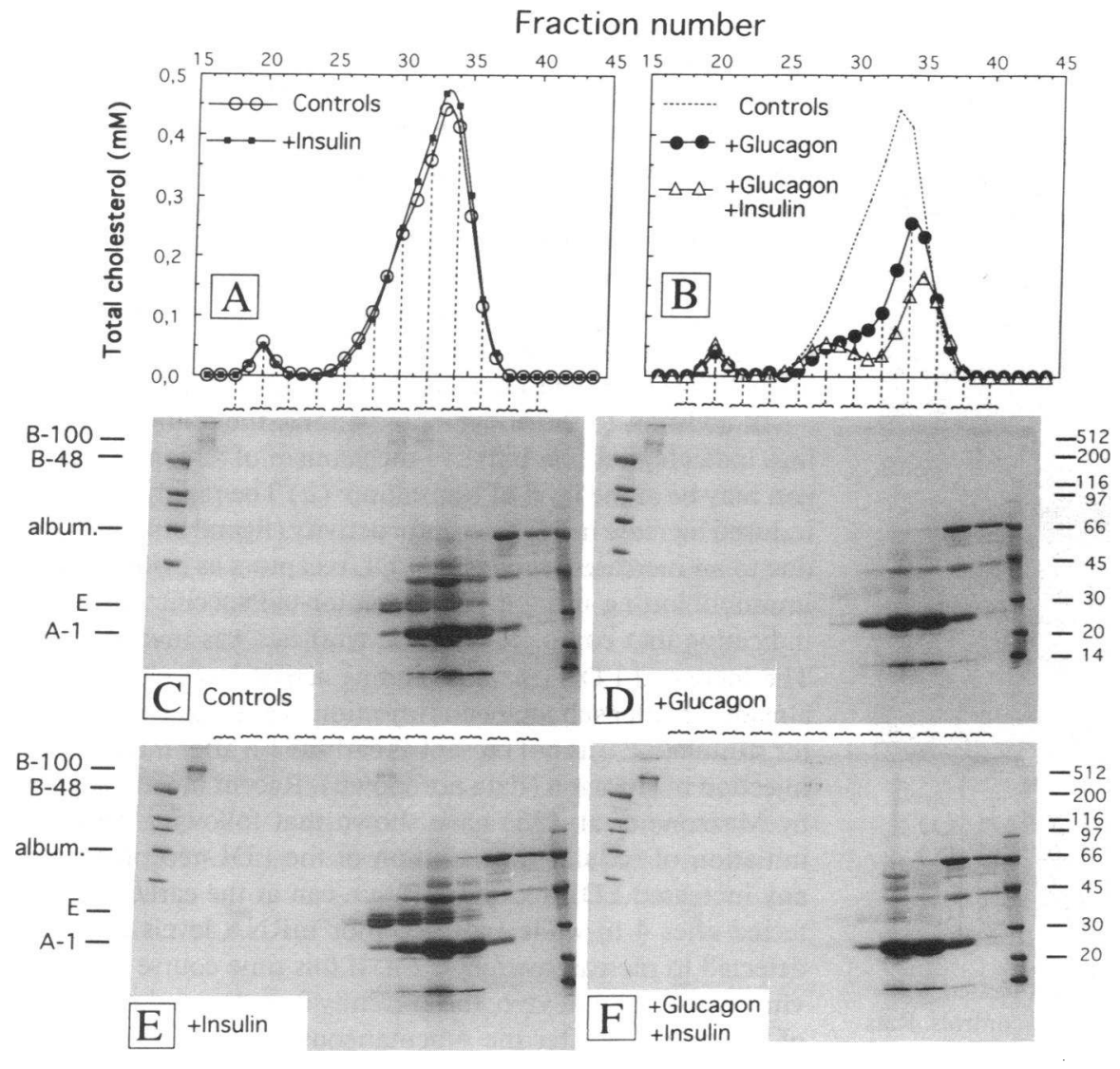

Figure 5. Characterization of plasma lipoproteins from the 4 groups of animals described in Table II. $(A$ and $B)$ Cholesterol concentration of FPLC-fractions: the animal groups are indicated. $(C-F)$ Coomassiestained SDS-PA gels after separation of the indicated delipidated FPLC fractions from controls $(C)$, glucagon-treated $(D)$, insulintreated $(E)$, and animals receiving combined treatment with insulin and glucagon $(F)$. Gel borders contain the indicated molecular weight markers. with glucagon and estrogen in combination (Fig. 7). In agreement with previous observations (this work and reference 8), determination of hepatic LDL-receptor binding activity revealed that glucagon-treated rats had a twofold, and rats receiving estrogen a fivefold increased binding (Fig. $7 A$ ). In addition to the $120-\mathrm{kD}$ band corresponding to the monomer of the LDL-receptor, a band around $230-240 \mathrm{kD}$, presumably the dimer of the LDL-receptor, was observed in estrogen-treated rats. The stimulation of LDL-receptor binding during estrogen treatment was unaltered upon additional treatment with glucagon (Fig. $7 A$ ). Quantitation of the LDL-receptor mRNA levels again showed that glucagon-treated animals had slightly reduced levels, while estrogen-treated animals, in agreement with previous findings $(8,11)$, showed a pronounced increase (Fig. $7 \mathrm{~B}$ ). However, among animals receiving glucagon and estrogen in combination, the mRNA levels were reduced to onethird of those seen in animals receiving estrogen only. Thus, addition of glucagon to estrogen-treated rats did not alter the estrogen-stimulated LDL-receptor expression, in spite of a strong glucagon-induced reduction of LDL-receptor mRNA levels. Total plasma cholesterol showed a clear inverse relation to hepatic LDL-receptor binding (Fig. $7 \mathrm{C}$ ), indicating that the hepatic LDL receptors were physiologically active, also during combined treatment. The effects of glucagon, estrogen as well as the presence of interaction were all highly significant for both receptor mRNA and plasma cholesterol levels (Fig. 7). Total hepatic cholesterol again showed a slight reduction in glucagon-treated animals, while estrogen-treated animals had elevated levels that were increased slightly further upon combination treatment (Fig. $7 C$ ). The dramatic reduction of lipo- protein cholesterol induced by estrogen treatment was not altered by the addition of glucagon (Fig. $7 \mathrm{D}$ ).

Finally, we proceeded to quantitate the number of LDL-receptors by immunoblot analysis of hepatic membranes from selected samples using a mouse monoclonal antibody directed against the intracellular carboxy-terminal 12 amino acids of the $L D L$ receptor. This antibody recognizes the $L D L$ receptor independent of the ligand-binding properties ( $\beta$-VLDL-binding) of the receptor. Samples from the time-course experiment of Fig. 2 (controls $=0 \mathrm{~h}, 3 \mathrm{~h}$, and $6 \mathrm{~h}$ post glucagon injection) were separated on SDS-PAGE. In addition, hepatic membranes from rats treated with estrogen were used as internal control (estrogen-treated group presented in the experiment displayed in Fig. 7).

As can be seen in Fig. 8, the sample from animals receiving only estrogen showed a $120-\mathrm{kD}$ band corresponding to the size of the LDL receptor. In comparison, this band was just barely detectable in normal rats (controls $=0 \mathrm{~h}$ ) under these conditions. However, in membranes from rats 3 and $6 \mathrm{~h}$ after glucagon injection, respectively, clearly increased LDL-receptor bands were seen. The relative changes in LDL-receptor ligand binding and antibody binding were highly proportional in the glucagon-treated animals (Fig. 9), indicating that the rapid increase in LDL-receptor ligand binding as shown in Fig. 2 was indeed due to an increased number of hepatic LDL receptors.

\section{Discussion}

The present investigation has established that the administration of glucagon to rats stimulates the expression of hepatic 


\section{Treatment}

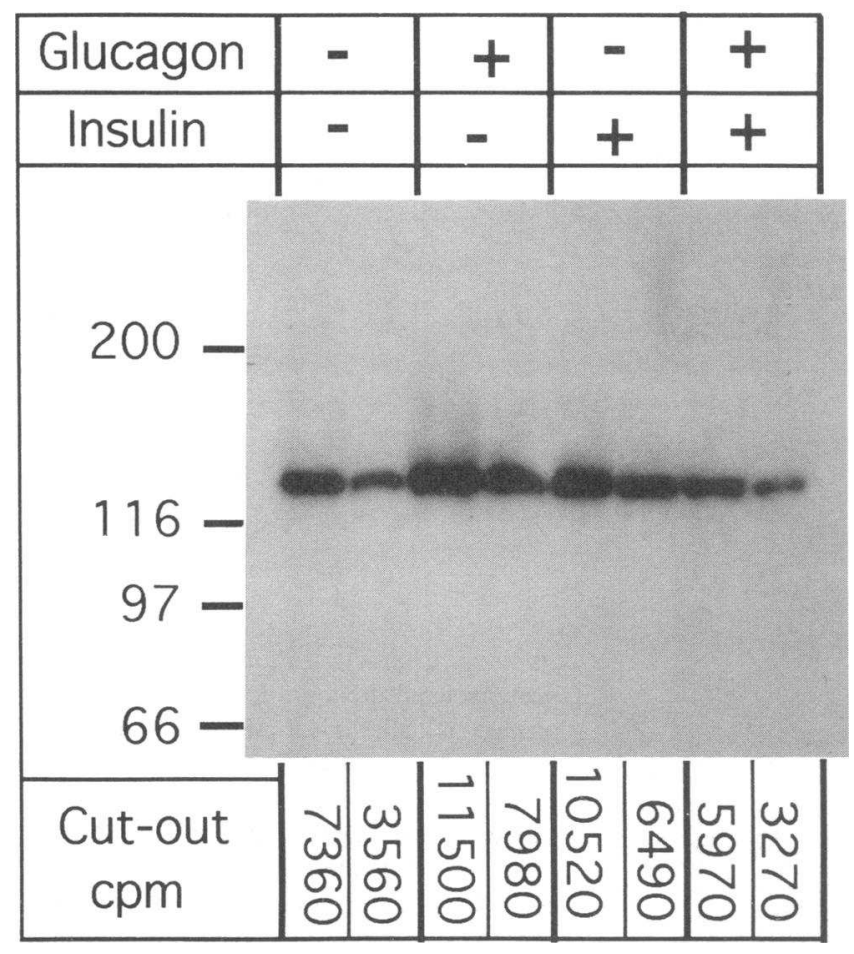

Figure 6. Ligand blot of hepatic membranes from rats treated with glucagon, insulin, and their combination in relation to controls. Rats (four per group) were treated as described in text to Table II. Hepatic membranes were prepared from pooled liver tissue from all rats in each group. For each group, two lanes with membrane protein were loaded ( 200 and $100 \mu \mathrm{g} /$ lane). After separation and subsequent transfer of proteins the filter was incubated with ${ }^{125} \mathrm{I}-\beta$-VLDL as described. The filter was exposed $2.5 \mathrm{~h}$, and subtracted filter background was $2,270 \mathrm{cpm}$.

LDL receptors as determined from ligand blot, using ${ }^{125} \mathrm{I}$-labeled rabbit $\beta$-VLDL, of hepatic membranes after SDS-PAGE separation. Receptor stimulation occurred already at a dose of $2 \times 4 \mu \mathrm{g}(1.2 \mathrm{nmol})$ daily, and was apparent already $3 \mathrm{~h}$ after glucagon injection. When the plasma lipoprotein pattern was analyzed by size-fractionation using gel chromatography, it was found that the glucagon-induced decrease of plasma cholesterol occurred within LDL and large HDL particles. Further analysis of the glucagon-mediated decrease of plasma cholesterol with time revealed that the initial decrease occurred within LDL and large HDL particles, and a detailed analysis of apolipoprotein patterns showed that apoB was reduced among LDL particles, and that apoE was almost eliminated from VLDL, LDL, and large HDL particles. Although glucagon is likely to have complex effects on lipoprotein secretion, metabolism, and interconversion, these findings are highly compatible with an increased physiological activity of hepatic LDL receptors $(1,35)$.

The mechanism for this LDL-receptor stimulation in the liver by glucagon is presently unknown. Taken together, several observations do however suggest that a principally new mechanism is involved, here to our knowledge first shown to occur in vivo: $(a)$ The LDL-receptor stimulation by glucagon was not related to increased levels of LDL-receptor mRNA; this is in contrast to what has been shown here and by others regarding hormones such as insulin $(9)$ and estrogen $(8,11)$. (b) In spite of unchanged LDL-receptor mRNA levels, the glucagon-induced receptor stimulation was abolished by concomitant insulin treatment. $(c)$ The receptor stimulation occurred in spite of increased levels of microsomal cholesterol. $(d)$ The receptor stimulation by glucagon occurred concomitantly with a reduced enzymatic activity of HMG CoA reductase. $(e)$ The hepatic LDL-receptor expression was essentially unchanged when glucagon was given together with estrogen, although the mRNA-levels for the LDL receptor were substantially reduced.

In addition to the above observations, the following findings indicate that one putative mechanism of action of glucagon may be at the level of translation: $(a)$ The rapid glucagoninduced increase in LDL-receptor activity (ligand binding) was due to an increased number of LDL receptors as evident from immunoblotting using a LDL-receptor-tail specific antibody, indicating that complete receptor synthesis was involved. (b) The increased LDL-receptor binding activity was clearly seen already $3 \mathrm{~h}$ after subcutaneous injection of glucagon, but receptor stimulation was not present as early as $1 \mathrm{~h}$ after intravenous injection of glucagon (data not shown). Recent in vitro studies by Mazzone et al. (36) have shown that following humoral initiation of cellular transcription of the LDL-receptor gene, any increased LDL-receptor protein can at the earliest be detected after $4 \mathrm{~h}$, while LDL-receptor mRNA levels could be detected to increase within $<2 \mathrm{~h}$. If this time course found in vitro is also valid in vivo, the currently found stimulation time of less than $3 \mathrm{~h}$ after the subcutaneous injection of glucagon would indicate that the current activation time is not sufficient to also involve transcription of the LDL-receptor gene. Further support for this conclusion was the fact that LDL-receptor mRNA levels were not increased upon glucagon treatment; instead, they were unchanged or reduced. However, from the present data we cannot exclude that glucagon in addition might also affect the recycling time or the intracellular fate of the LDL receptor-two other putative mechanisms of posttranscriptional regulation.

A posttranscriptional stimulation of LDL-receptor activity may also explain the findings of reduced mRNA levels upon glucagon administration. A rapid increase in the hepatic LDLreceptor number should likely result in increased cellular cholesterol, as was also found within hepatic microsomes. This may lead to a reduced transcription of the gene for the LDL receptor by end-product inhibition. Additional support for this possibility was the fact that the enzymatic activity of HMGCoA reductase (maximal activity) was severely reduced upon glucagon treatment (Table I). Previous studies have shown that the activity of this enzyme is strongly and rapidly reduced by cholesterol $(1,37)$.

The role of glucagon in cholesterol metabolism is still open to discussion. Pharmacological doses of glucagon were used in the present study, but the dose-response experiments clearly showed that also much lower doses of glucagon increased the hepatic LDL-receptor binding. It has been shown that experimental and pathological states with elevated glucagon levels are associated with decreased plasma cholesterol levels (2022). The present findings may thus not only be relevant for explaining the reduced LDL levels in patients with glucagonoma (19), but could indicate a physiological role of this hormone in the regulation of plasma LDL levels. Several stimuli 


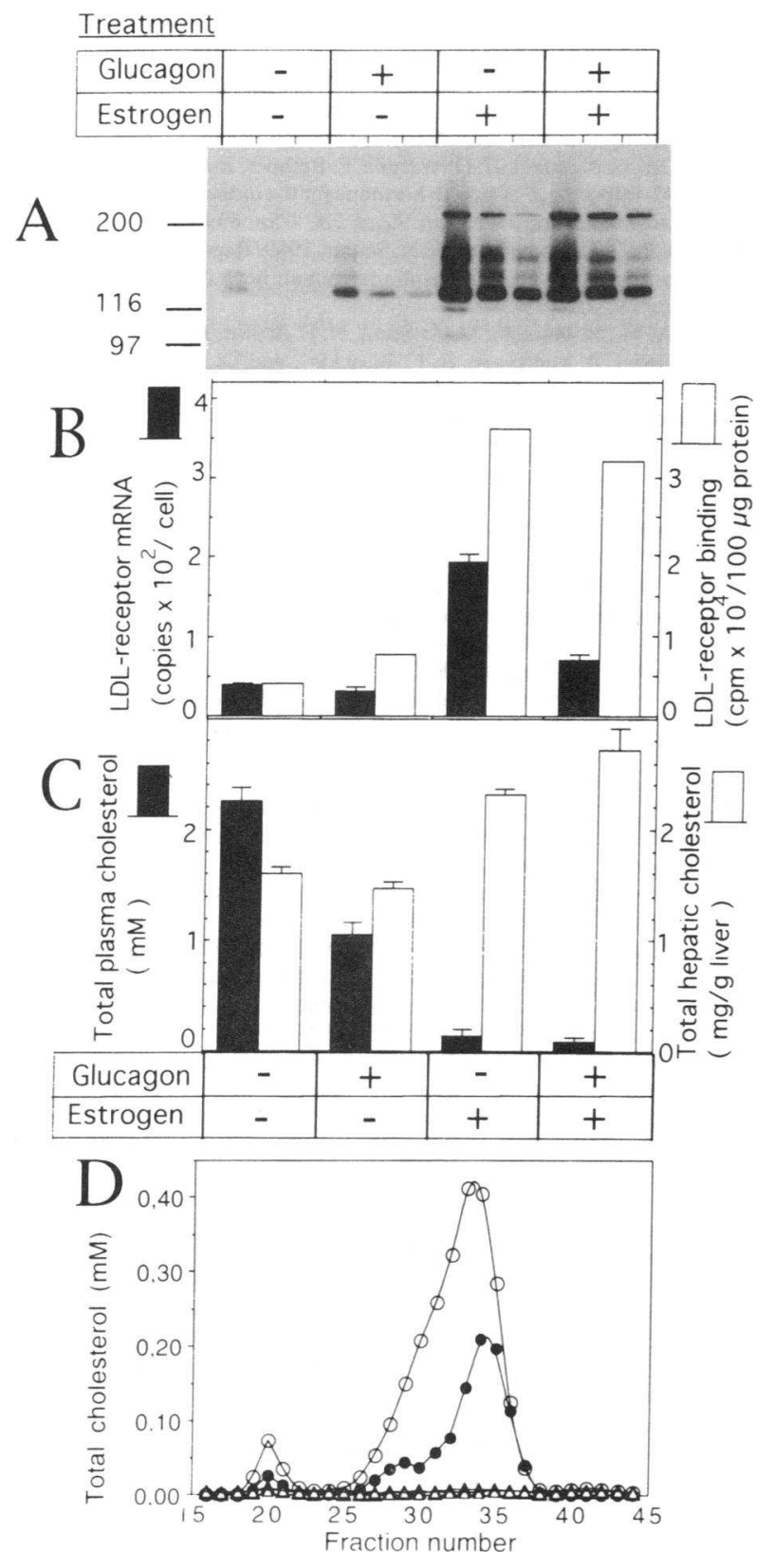

Figure 7. Comparison of effects of treatment with glucagon, estrogen, and glucagon + estrogen to vehicle-treated rats (controls). Groups of four male rats were injected for $4 \mathrm{~d}$ with saline, glucagon $(400 \mu \mathrm{g}$ $\times 2$ ), estrogen ( $5 \mathrm{mg} / \mathrm{kg}$ per $\mathrm{d}$ (morning)), or with the combination of the two hormones. On day 5 , animals were killed $3 \mathrm{~h}$ after receiving the morning dose. $A$ shows a ligand blot of separated hepatic membranes prepared from pooled liver tissues from each group. Three lanes were run for each rat group containing 100,50 , and $25 \mu \mathrm{g}$ protein/lane. $(B)$ The quantitated LDL-receptor ligand binding activity (open columns) derived from the blot in $A$ (the filter was exposed for $4 \mathrm{~h}$ and subtracted background radioactivity was $420 \mathrm{cpm}$ ) and the LDL-receptor mRNA abundancy (filled columns); bars = SEM. Total plasma and hepatic cholesterol concentrations are shown in $C$. The cholesterol content in fractions of plasma after separation by FPLC is shown in $D(0=$ control rats; $\bullet$ = glucagon-treated; $\Delta=$ estrogentreated; $\Delta=$ estrogen + glucagon-treated rats). Factor test for significance (effect of glucagon only, estrogen only, or presence of interaction during combined treatment) was highly significant for all three factors as regards LDL-receptor mRNA and serum cholesterol ( $P$

\begin{tabular}{|l|c|c|c|c|}
\hline Estrogen & + & - & - & - \\
\hline Glucagon & - & $0 \mathrm{~h}$ & $+3 \mathrm{~h}$ & $+6 \mathrm{~h}$ \\
\hline
\end{tabular}

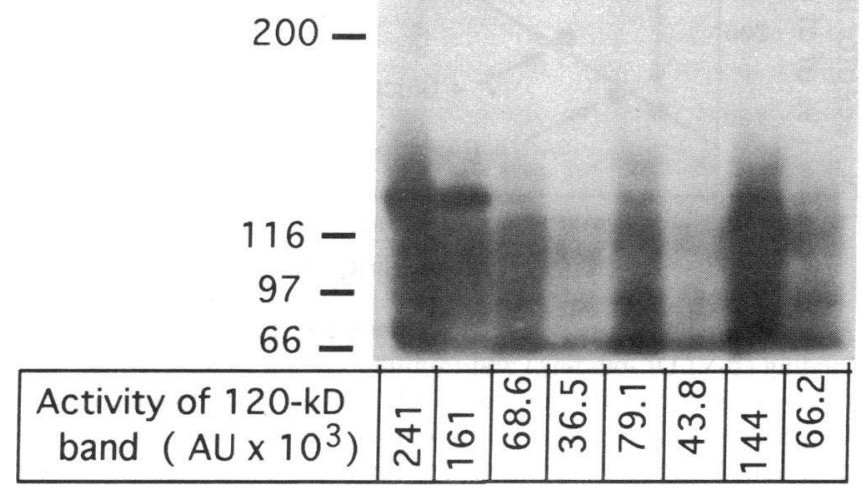

Figure 8. Immunoblot of hepatic membranes using an antipeptide antibody directed against the intracellular carboxy-terminal 12 amino acids of the tail of the LDL receptor. Samples from control rats, estrogen-treated rats, and rats that had received a bolus of glucagon $3 \mathrm{~h}$ and $6 \mathrm{~h}$ prior to killing, respectively. For each group, two lanes were loaded with 100 and $200 \mu \mathrm{g}$ of membrane protein on SDS-PA gel. After transfer of proteins, the filter was incubated with IgG-4A4 ( 1 $\mu \mathrm{g} / \mathrm{ml}$ ), washed and subsequently incubated with ${ }^{125} \mathrm{I}$-labeled goat anti-mouse antibody $\left(2 \times 10^{6} \mathrm{cpm} / \mathrm{ml}\right)$. The filter was finally exposed to $\mathrm{x}$-ray film for $4 \mathrm{~h}$ at $-70^{\circ} \mathrm{C}$. Quantitation of the activity in $120-\mathrm{kD}$ bands was made using a PhosphorImager ${ }^{\circledR}$ as described. Numbers are arbitrary units (AU), after subtraction of background $6,075 \mathrm{AU}$.

are known to release glucagon:, e.g., insulin-induced hypoglycemia, arginine, dopamine, neurotensin, substance $P(38)$, and growth hormone (39). Of particular interest are observations showing that glucagon is rapidly released following dietary fat, and that the fat-induced glucagon release is abolished if proceeded by glucose administration (40). In this context it must be remembered that, following endogenous release of glucagon from the gut or pancreas, the portal levels of glucagon are at least twofold higher than those measured in peripheral plasma (19).

At present, in order to reduce plasma LDL cholesterol levels, hepatic LDL-receptor stimulation is obtained by pharmacological or dietary treatments, all based on the common rationale that a pool of hepatic (microsomal) cholesterol is transiently reduced, leading to an increased transcription of the LDL-receptor gene, which itself results in elevated LDL-receptor mRNA levels and a consequent increase in receptor number (1). Concomitant with LDL receptor stimulation there is an increased synthesis of cholesterol via HMG-CoA reductase, a response that will reduce the magnitude of LDL-receptor stimulation. The current data show that hepatic LDL-receptors can be rapidly induced in spite of increased cholesterol levels

$<0.005)$. Factor analysis of the data for hepatic cholesterol showed that the effect of estrogen, as well as the presence of interaction, were significant $(P<0.005$ and $<0.025$, respectively). No significant effect was obtained for glucagon. 


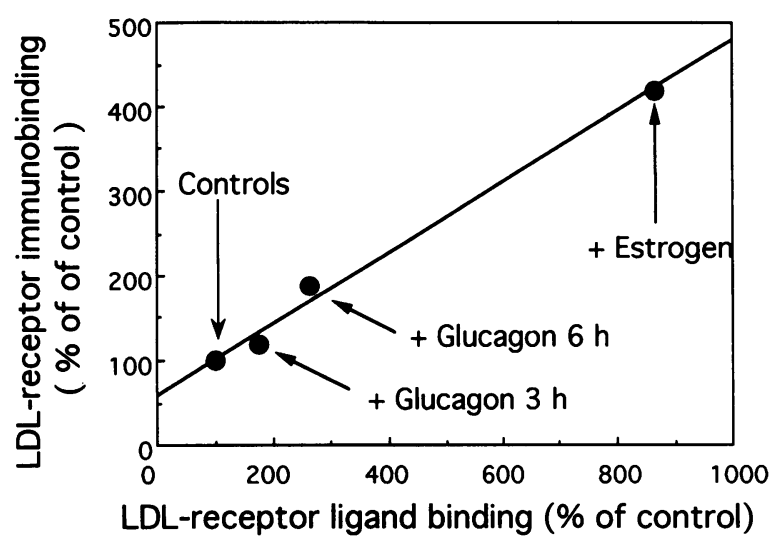

Figure 9. Relation between relative changes in LDL-receptor ligand binding ( $\beta$-VLDL-binding) and immunobinding using a mouse monoclonal antipeptide antibody (IgG-4A4). Ligand binding data for glucagon-treatment and estrogen treatment were derived from the quantitated blot of the time-course experiment (Fig. 2; 3 and $6 \mathrm{~h}$ postglucagon injection), and from Fig. 7 (estrogen treated). Data for immunobinding were obtained from the quantitated $120-\mathrm{kD}$ bands presented in Fig. 8. The data is expressed as percent related to the respective untreated controls that were set to $100 \% . r=+0.995$.

within hepatic microsomes, and concomitant with a reduced activity of $\mathrm{HMG} \mathrm{CoA}$ reductase. In addition, the present results strongly suggest that hepatic LDL receptors may be induced independently of the LDL-receptor mRNA level. The molecular mechanisms underlying the glucagon-mediated hepatic LDL-receptor stimulation must now be elucidated, since the presence of such a novel mechanism would have important therapeutic implications.

\section{Acknowledgments}

We thank Ms. Ingela Arvidsson, Ms. Camilla Ejdestig, and Ms Tatiana Egereva for expert technical assistance, Dr. Michael S. Brown and Dr. Y. K. Ho, for kindly providing us with the monoclonal antibody IgG4A4, Dr. J. Rudling for help with statistical analysis of the data, and Ms. Lena Ericsson for editorial assistance.

This work is supported by the Swedish Medical Research Council (03X-7137, 03K-8722), the Nordic Insulin Fund, and the Wiberg, Osterman, Turing and Goljes Foundations.

\section{References}

1. Brown, M. S., and J. L. Goldstein. 1986. A receptor-mediated pathway for cholesterol homeostasis. Science (Wash. DC). 232:34-47.

2. Myant, N. B. 1990. Cholesterol Metabolism, LDL, and the LDL Receptor. Academic Press, San Diego. 465 pp.

3. Kovanen, P. T., D. W. Bilheimer, J. L. Goldstein, J. J. Jaramillo, and M. S. Brown. 1981. Regulatory role for hepatic low density lipoprotein receptors in vivo in the dog. Proc. Natl. Acad. Sci. USA. 78:1194-1198.

4. Rudling, M., E. Reihnér, K. Einarsson, S. Ewerth, and B. Angelin. 1990. Low density lipoprotein receptor-binding activity in human tissues: Quantitative importance of hepatic receptors and evidence for regulation of their expression in vivo. Proc. Natl. Acad. Sci. USA. 87:3469-3473.

5. Reihnér, E., M. Rudling, D. Ståhlberg, L. Berglund, S. Ewerth, I. Björkhem, K. Einarsson, and B. Angelin. 1990. Influence of pravastatin, a specific inhibitor of HMG CoA reductase, on hepatic metabolism of cholesterol. N. Engl. J. Med. 323:224-228.

6. Kovanen, P. T., M. S. Brown, and J. L. Goldstein. 1979. Increased binding of low density lipoprotein to liver membranes from rats treated with 17 alpha-ethinyl estradiol. J. Biol. Chem. 254:11367-11373.

7. Angelin, B., H. Olivecrona, E. Reihnér, M. Rudling, D. Ståhlberg, M. Eriksson, S. Ewerth, P. Henriksson, and K. Einarsson. 1992. Hepatic cholesterol metabolism in estrogen-treated men. Gastroenterology. 103:1657-1663.

8. Rudling, M., G. Norstedt, H. Olivecrona, E. Reihnér, J.-Ä. Gustafsson, and B. Angelin. 1992. Importance of growth hormone for the induction of hepatic low density lipoprotein receptors. Proc. Natl. Acad. Sci. USA. 89:6983-6987.

9. Wade, D. P., B. L. Knight, and A. K. Soutar. 1989. Regulation of low-density-lipoprotein receptor mRNA by insulin in human hepatoma Hep G2 cells. Eur. J. Biochem. 181:727-731.

10. Salter, A. M., R. Hayashi, M. Al-Seeni, N. F. Brown, J. Bruce, O. Sorensen, E. A. Atkinson, B. Middleton, R. C. Bleackley, and D. N. Brindley. 1991 Effects of hypothyroidism and high-fat feeding on mRNA concentrations for the low-density-lipoprotein receptor and on acyl-CoA: cholesterol acyltransferase activities in rat liver. Biochem. J. 276:825-832.

11. Ma, P. T., T. Yamamoto, J. L. Goldstein, and M. S. Brown. 1986. Increased mRNA for low density lipoprotein receptor in livers of rabbits treated with 17 alpha-ethinyl estradiol. Proc. Natl. Acad. Sci. USA. 83:792-796.

12. Ma, P. T., T. Gil, T. C. Südhof, D. W. Bilheimer, J. L. Goldstein, and M. S. Brown. 1986. Mevinolin, an inhibitor of cholesterol synthesis, induces mRNA for low density lipoprotein receptors in livers of hamsters and rabbits. Proc. Natl. Acad. Sci. USA. 83:8370-8374.

13. Rudling, M. 1992. Hepatic mRNA levels for the LDL receptor and HMGCoA reductase show coordinate regulation in vivo. J. Lipid Res. 33:493-501.

14. Sharkey, M. F., A. Miyanohara, R. L. Elam, T. Friedmann, and J. L. Witztum. 1990. Post-transcriptional regulation of retroviral vector-transduced low density lipoprotein receptor activity. J. Lipid Res. 31:2167-2178.

15. Ellsworth, J. L., C. Chandrasekaran, and A. D. Cooper. 1991. Evidence for sterol-independent regulation of low-density lipoprotein receptor activity in HepG2 cells. Biochem. J. 279:175-187.

16. Middleton, B., and A. Middleton. 1992. Cyclic AMP stimulates the synthesis and function of the low-density lipoprotein receptor in human vascular smooth-muscle cells and fibroblasts. Biochem. J. 282:853-861.

17. Grove, R. I., C. E. Mazzucco, S. F. Radka, M. Shoyab, and P. A. Kiener. 1991. Oncostatin M upregulates low density lipoprotein receptors in HepG2 cells by a novel mechanism. J. Biol. Chem. 266:18194-18199.

18. Tam, S-P., L. Brissette, R. Ramharack, and R. G. Deeley. 1991. Differences between the regulation of 3-hydroxy-3-methylglutaryl coenzyme $A$ reductase and low density lipoprotein receptor in human hepatoma cells and fibroblasts reside primarily at the translational and post-translational levels. J. Biol. Chem. 266:16764-16773.

19. Unger, R. H. 1983. The Berson memorial lecture. Insulin-glucagon relationships in the defense against hypoglycemia. Diabetes. 32:575-583.

20. Vaughan, G. M., R. A. Becker, R. H. Unger, M. G. Ziegler, T. M. SilerKhodr, B. A. Pruitt, and A. D. Mason, Jr. 1985. Nonthyroidal control of metabolism after burn injury: possible role of glucagon. Metab. Clin. Exp. 34:637-641.

21. Isselbacher, K. J., R. D. Adams, E. Braunwald, R. G. Petersdorf, and J. D. Wilson. 1980. Harrison's Principles of Internal Medicine. 9th ed. McGraw-Hill Book Co., New York. 1764 pp.

22. Knapp, M. L., S. Al-Sheibani, and P. G. Riches. 1991. Alterations of serum lipids in breast cancer: effects of disease activity, treatment, and hormonal factors. Clin. Chem. 37:2093-2101.

23. Amatuzio, D. S., F. Grande, and S. Wada. 1962. Effect of glucagon on the serum lipids in essential hyperlipidemia and in hypercholesterolemia. Metab. Clin. Exp. 11:1240-1249.

24. Eaton, R. P. 1973. Hypolipidemic action of glucagon in experimental endogenous hyperlipidemia in the rat. J. Lipid Res. 14:312-318.

25. Guettet, C., N. Rostaqui, D. Mathé, B. Lecuyer, N. Navaro, and B. Jacotot. 1991. Effect of chronic glucagon administration on lipoprotein composition in normally fed, fasted, and cholesterol-fed rats. Lipids. 26:451-458.

26. Paloyan, E., and P. W. Harper, Jr. 1961. Glucagon as a regulating factor of plasma lipids. Metab. Clin. Exp. 10:315-323.

27. Caren, R., and L. Carbo. 1956. Pancreatic alpha-cell function in relation to cholesterol metabolism. J. Clin. Endocrinol. Metab. 16:507-516.

28. Brown, N. F., A. M. Salter, R. Fears, and D. N. Brindley. 1989. Glucagon, cyclic AMP and adrenaline stimulate the degradation of low density lipoprotein by cultured rat hepatocytes. Biochem. J. 262:425-429.

29. Ha, Y. C., and P. J. Barter. 1985. Rapid separation of plasma lipoproteins by gel permeation chromatography on agarose gel superose 6B. J. Chromatog. 341:154-159.

30. van Driel, I. R., J. L. Goldstein, T. C. Südhof, and M. S. Brown. 1987. First cysteine-rich repeat in ligand-binding domain of low density lipoprotein receptor binds $\mathrm{Ca}^{2+}$ and monoclonal antibodies, but not lipoproteins. J. Biol. Chem. 262:17443-17449.

31. Angelin, B., K. Einarsson, L. Liljeqvist, K. Nilsell, and R. A. Heller. 1984. 3-hydroxy-3-methylglutaryl coenzyme A reductase in human liver microsomes: 
active and inactive forms and cross-reactivity with antibody against rat liver enzyme. J. Lipid Res. 25:1159-1166.

32. Einarsson, K., B. Angelin, S. Ewerth, K. Nilsell, and I. Björkhem. 1986. Bile acid synthesis in man: assay of hepatic microsomal cholesterol 7 alpha-hydroxylase activity by isotope dilution-mass spectrometry. J. Lipid Res. 27:82-88.

33. Snedecor G. W., and W. G. Cochran. Statistical methods. 7th ed., 1980. The Iowa State University Press, Ames, IA. 507 pp.

34. Rudling, M. 1987. Role of the liver for the receptor-mediated catabolism of low density lipoprotein in the $17 \alpha$-ethinylestradiol treated rat. Biochim. Biophys. Acta. 919:175-180.

35. Mahley, R. W. 1988. Apolipoprotein E: cholesterol transport protein with expanding role in cell biology. Science (Wash. DC). 240:622-630.

36. Mazzone, T., K. Basheeruddin, L. Ping, S. Frazer, and G. S. Getz. 1989.
Mechanism of the growth-related activation of the low-density lipoprotein receptor pathway. J. Biol. Chem. 264:1787-1792.

37. Goldstein, J. L., and M. S. Brown. 1990. Regulation of the mevalonate pathway. Nature (Lond.). 343:425-430.

38. Moltz, J. H., R. E. Dobbs, S. M. McCann, and C. D. Fawcett. 1976. Effects of hypothalamic factors on insulin and glucagon release from the islets of langerhans. Endocrinology. 101:196-202.

39. Vaitkus, P., A. Sirek, K. H. Norwich, O. V. Sirek, R. H. Unger, and V. Harris. 1984. Rapid changes in hepatic glucose output after a pulse of growth hormone in dogs. Am. J. Physiol. 246:E14-E20.

40. Dobbs, R., G. R. Faloona, and R. H. Unger. 1975. Effect of intravenously administered glucose on glucagon and insulin secretion during fat absorption. Metab. Clin. Exp. 24:69-75. 